\title{
Front Matter: Volume 8234
}

, "Front Matter: Volume 8234," Proc. SPIE 8234, Plasmonics in Biology and Medicine IX, 823401 (16 February 2012); doi: 10.1117/12.923381

SPIE. Event: SPIE BiOS, 2012, San Francisco, California, United States 


\section{Plasmonics in Biology and Medicine IX}

Tuan Vo-Dinh

Joseph R. Lakowicz

Editors

22-24 January 2012

San Francisco, California, United States

Sponsored and Published by

SPIE

Volume 8234

Proceedings of SPIE, 1605-7422, v. 8234

SPIE is an international society advancing an interdisciplinary approach to the science and application of light. 
The papers included in this volume were part of the technical conference cited on the cover and title page. Papers were selected and subject to review by the editors and conference program committee. Some conference presentations may not be available for publication. The papers published in these proceedings reflect the work and thoughts of the authors and are published herein as submitted. The publisher is not responsible for the validity of the information or for any outcomes resulting from reliance thereon.

Please use the following format to cite material from this book:

Author(s), "Title of Paper," in Plasmonics in Biology and Medicine IX, edited by Tuan Vo-Dinh, Joseph R. Lakowicz, Proceedings of SPIE Vol. 8234 (SPIE, Bellingham, WA, 2012) Article CID Number.

ISSN $1605-7422$

ISBN 9780819488770

Published by

SPIE

P.O. Box 10, Bellingham, Washington 98227-0010 USA

Telephone +1 3606763290 (Pacific Time) · Fax +1 3606471445

SPIE.org

Copyright (C) 2012, Society of Photo-Optical Instrumentation Engineers.

Copying of material in this book for internal or personal use, or for the internal or personal use of specific clients, beyond the fair use provisions granted by the U.S. Copyright Law is authorized by SPIE subject to payment of copying fees. The Transactional Reporting Service base fee for this volume is $\$ 18.00$ per article (or portion thereof), which should be paid directly to the Copyright Clearance Center (CCC), 222 Rosewood Drive, Danvers, MA 01923. Payment may also be made electronically through CCC Online at copyright.com. Other copying for republication, resale, advertising or promotion, or any form of systematic or multiple reproduction of any material in this book is prohibited except with permission in writing from the publisher. The CCC fee code is 1605$7422 / 12 / \$ 18.00$.

Printed in the United States of America.

Publication of record for individual papers is online in the SPIE Digital Library.

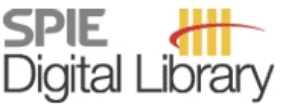

SPIEDigitalLibrary.org

Paper Numbering: Proceedings of SPIE follow an e-First publication model, with papers published first online and then in print and on CD-ROM. Papers are published as they are submitted and meet publication criteria. A unique, consistent, permanent citation identifier (CID) number is assigned to each article at the time of the first publication. Utilization of CIDs allows articles to be fully citable as soon as they are published online, and connects the same identifier to all online, print, and electronic versions of the publication. SPIE uses a six-digit CID article numbering system in which:

- The first four digits correspond to the SPIE volume number.

- The last two digits indicate publication order within the volume using a Base 36 numbering system employing both numerals and letters. These two-number sets start with 00, 01, 02, 03, 04, $05,06,07,08,09,0 A, 0 B \ldots$. 0Z, followed by 10-1Z, 20-2Z, etc.

The CID number appears on each page of the manuscript. The complete citation is used on the first page, and an abbreviated version on subsequent pages. Numbers in the index correspond to the last two digits of the six-digit CID number. 


\section{Contents}

ix Conference Committee

SESSION 1 PLASMONICS AND SERS I

823404 SERS enhancement of Ag nanoparticle patterns embedded in glass by two-step ion exchange [8234-04]

L. Karvonen, Y. Chen, A. Säynätjoki, A. Tervonen, Aalto Univ. (Finland); S. Honkanen, Aalto Univ. (Finland) and Univ. of Eastern Finland (Finland)

823405 Plasmonic nanostructures on the basis of Ag covered PMMA gratings [8234-05] M. Zeisberger, Institut für Photonische Technologien e.V. (Germany); K. Weber, Institut für Photonische Technologien e.V. (Germany) and Friedrich-Schiller-Univ. Jena (Germany); U. Hübner, H. Schneidewind, R. Mattheis, Institut für Photonische Technologien e.V. (Germany); D. Cialla, J. Popp, Institut für Photonische Technologien e.V. (Germany) and Friedrich-Schiller-Univ. Jena (Germany)

823406 Optimization of SERS enhancement from nanostructured metallic substrate based on arrays of inverted rectangular pyramids and investigation of effect of lattice non-symmetry [8234-06]

S. Z. Oo, M. D. B. Charlton, Univ. of Southampton (United Kingdom); D. Eustace, Renishaw Diagnostics Ltd. (United Kingdom); R. Y. Chen, S. J. Pearce, M. E. Pollard, Univ. of Southampton (United Kingdom)

\section{SESSION 2 PLASMONICS AND SERS II}

823407 Surface-enhanced Raman scattering for label-free protein detection and identification [8234-07]

M. Çulha, S. Keskin, Yeditepe Univ. (Turkey)

823409 Controllable cavity rim opening of up-right nanocrescents leading to repeatable SERS measurements [8234-09]

H. M. Chen, L. Pang, Univ. of California, San Diego (United States); A. King, Renishaw Corp. (United States); G. M. Hwang, The MITRE Corp. (United States); Y. Fainman, Univ. of California, San Diego (United States)

$8234 \mathrm{OA}$ Surface-enhanced Raman scattering and microwave absorption in silver nanoparticle inks [8234-10] M. Figueroa, Drexel Univ. (United States); S. Schraer, Villanova Univ. (United States); K. Pourrezaei, S. Tyagi, Drexel Univ. (United States)

$8234 \mathrm{OB} \quad$ Fluorescence enhancement using silver-gold nanocomposite substrates [8234-63] S. Dutta Choudhury, R. Badugu, K. Ray, P. Sai Vanam, J. R. Lakowicz, Univ. of Maryland at Baltimore (United States) 
8234 OC Nanobiophotonics for molecular imaging of cancer: Au- and Ag-based epidermal growth factor receptor (EGFR) specific nanoprobes [8234-11]

L. J. Lucas, K. C. Hewitt, Dalhousie Univ. (Canada)

8234 OD Intravital confocal Raman microscopy with multiplexed SERS contrast agents [8234-12]

P. Z. McVeigh, Univ. of Toronto (Canada); B. C. Wilson, Univ. of Toronto (Canada) and Univ. Health Network (Canada)

8234 OE Molecular imaging with surface-enhanced CARS on nanostructures [8234-13]

C. Steuwe, C. F. Kaminski, J. J. Baumberg, S. Mahajan, Univ. of Cambridge (United Kingdom)

$8234 \mathrm{OF}$ Intracellular multiplex detection and imaging of stable chemisorbed labels by SERS spectroscopy [8234-14]

N. M. S. Sirimuthu, C. D. Syme, J. M. Cooper, Univ. of Glasgow (United Kingdom)

\section{SESSION 4 PLASMONIC BIOSENSING}

$8234 \mathrm{OH} \quad$ A magnetic-field enriched surface-enhanced resonance Raman spectroscopy strategy towards the early diagnosis of malaria [8234-17]

C. Yuen, Q. Liu, Nanyang Technological Univ. (Singapore)

8234 Ol Characterization of individual microdroplets by SERRS spectroscopy [8234-18]

C. D. Syme, N. Sirimuthu, C. Martino, R. Yusvana, J. M. Cooper, Univ. of Glasgow (United Kingdom)

$82340 \mathrm{~J}$ Experimental investigation of droplet biosensing by multi-wavelength plasmonic [8234-19] C. Desfours, HoloLab, Univ. de Liège (Belgium); S. Habraken, HoloLab, Univ. de Liège (Belgium) and Ctr. Spatial de Liège, Univ. de Liège (Belgium); J. Hastanin, C. Lenaerts, K. Fleury-Frenette, Ctr. Spatial de Liège, Univ. de Liège (Belgium)

$8234 \mathrm{OK}$ Ultrasensitive system for the real-time detection of $\mathrm{H}_{2} \mathrm{O}_{2}$ based on strong coupling in a bioplasmonic system [8234-20]

S. Dutta-Gupta, G. Suarez, C. Santschi, Ecole Polytechnique Fédérale de Lausanne (Switzerland); L. Juillerat-Jeanneret, Institute of Pathology, Univ. of Lausanne (Switzerland);

O. J. F. Martin, Ecole Polytechnique Fédérale de Lausanne (Switzerland)

8234 OL Development of LSPR and SPR sensor for the detection of an anti-cancer drug for chemotherapy [8234-55]

S. S. Zhao, Univ. de Montréal (Canada); O. R. Bolduc, Cornell Univ. (Canada); D. Y. Colin, J. N. Pelletier, J.-F. Masson, Univ. de Montréal (Canada)

\section{SESSION 5 PLASMONIC NANOSTRUCTURES}

8234 OM Plasmon-controlled fluorescence and single DNA strand sequencing (Invited Paper) [8234-21]

N. Akbay, K. Ray, M. H. Chowdhury, J. R. Lakowicz, Univ. of Maryland at Baltimore (United States) 
823400 Localized surface plasmonic resonant based on bowtie type metallic nanostructure [8234-23]

T. Luo, L. Pang, W. Zhang, M. Chen, Guangxi Univ. (China)

8234 OP Hybrid nanoparticle and thin film SPR biosensor with a high figure of merit [8234-24] A. Farhang, B. Abasahl, O. J. F. Martin, Nanophotonics and Metrology Lab., Ecole Polytechnique Fédérale de Lausanne (Switzerland)

8234 OR Radiative-SPR plafform for the detection of apolipoprotein E for use in medical diagnostics [8234-26]

B. Sciacca, A. Francois, M. A. S. Penno, J. A. Brazzatti, M. Klingler-Hoffmann, P. Hoffmann, T. M. Monro, The Univ. of Adelaide (Australia)

\section{SESSION 6 PLASMONICS AND FLUORESCENCE I}

8234 OS Controlled fluorescence emission via surface modes on dielectric and metallo-dielectric multistack [8234-27]

M. Ballarini, F. Frascella, Politecnico di Torino (Italy); N. de Leo, E. Enrico, National Institute of Metrological Research (Italy); P. Rivolo, Politecnico di Torino (Italy); F. Michelotti, Univ. degli Studi di Roma La Sapienza (Italy); F. Giorgis, Politecnico di Torino (Italy); E. Descrovi, Politecnico di Torino (Italy) and Italian Institute of Technology (Italy)

$8234 \mathrm{OV}$ Surface plasmon enhanced-field fluorescence biosensor for point-of-care testing using fluorescent nanoparticles [8234-30]

K. Horii, T. Kimura, H. Ohtsuka, N. Kasagi, T. Oohara, T. Matsuno, M. Hakamata, A. Komatsu, T. Sendai, FUJIFILM Corp. (Japan)

\section{SESSION 7 PLASMONICS AND FLUORESCENCE II}

8234 OW Fluorescence enhancements and spectral modifications near the cut-off frequency of plasmonic structure [8234-31]

K. Elsayad, Research Institute of Molecular Pathology (Austria); A. Urich, Technische Univ. Wien (Austria); M. Nemethova, J. V. Small, Institute of Molecular Biotechnology GmbH (Austria); K. Unterrainer, Technische Univ. Wien (Austria); K. G. Heinze, Research Institute of Molecular Pathology (Austria) and Univ. of Würzburg (Germany)

$82340 Z$ Multifunctional gold nanorods for image-guided surgery and photothermal therapy [8234-34]

C. Barriere, J. Qi, P. B. Garcia-Allende, R. Newton, D. S. Elson, Imperial College London (United Kingdom)

\section{SESSION $8 \quad$ PLASMONIC APPLICATIONS I}

823412 Characterization and performance of commercial localized surface plasmon resonance chips [8234-38]

D. Gerion, LamdaGen Corp. (United States) 
823414 Analysis of spectral-phase conventional and long-range surface plasmon resonance biosensors [8234-40]

C. Wang, The Chinese Univ. of Hong Kong (Hong Kong, China) and Tsinghua Univ. (China); H.-P. Ho, The Chinese Univ. of Hong Kong (Hong Kong, China); P. Shum, Nanyang Technological Univ. (Singapore)

823417 Distance-dependent intrinsic fluorescence of proteins on aluminum nanostructures [8234-64]

N. Akbay, J. R. Lakowicz, K. Ray, Univ. of Maryland at Baltimore (United States)

823419 Infrared surface plasmon spectroscopy and biosensing [8234-44]

V. Yashunsky, A. Zilbershtein, V. Lirtsman, T. Marciano, B. Aroeti, M. Golosovsky, D. Davidov, The Hebrew Univ. of Jerusalem (Israel)

8234 1A Dynamical sequence of Au plasmonic nanopore formation using high energy electron beam exposure [8234-45]

T. Yamaguchi, SunMoon Univ. (Korea, Republic of); M. J. Park, Korea Military Academy (Korea, Republic of); D. S. Kim, N. K. Park, Seoul National Univ. (Korea, Republic of); S. S. Choi, SunMoon Univ. (Korea, Republic of)

8234 IC Novel biosensor for detecting hemoglobin and its oxidation state based on nonreciprocity in a coupled waveguide system [8234-47]

S. Dutta-Gupta, O. J. F. Martin, Ecole Polytechnique Fédérale de Lausanne (Switzerland);

S. Dutta Gupta, Univ. of Hyderabad (India)

$8234 \mathrm{IF}$ Plasmonic nanobubbles for cell theranostics [8234-15]

E. Y. Lukianova-Hleb, S. Kashinath, D. O. Lapotko, Rice Univ. (United States)

POSTER SESSION

8234 IG Surface-enhanced Raman spectroscopy of pterins [8234-37]

C. A. Smyth, I. Mirza, J. G. Lunney, E. M. McCabe, Trinity College Dublin (Ireland)

$8234 \mathrm{1H}$ Integrated waveguide sensor plafform utilizing organic photodiodes [8234-50] B. Lamprecht, M. Sagmeister, E. Kraker, P. Hartmann, G. Jakopic, S. Köstler, JOANNEUM RESEARCH Forschungsgesellschaft mbH (Austria); H. Ditlbacher, N. Galler, J. Krenn, Karl-Franzens-Univ. Graz (Austria); B. Ungerböck, T. Abel, T. Mayr, Technische Univ. Graz (Austria)

$8234 \mathrm{lJ} \quad$ Single cell targeting using plasmon resonant gold-coated liposomes [8234-52] S. J. Leung, M. Romanowski, The Univ. of Arizona (United States)

8234 iN Surface plasmon resonance sensing using index-matched metallic nano-hole array structures [8234-57]

M. Najiminaini, Simon Fraser Univ. (Canada) and Lawson Health Research Institute (Canada); F. Vasefi, Simon Fraser Univ. (Canada), Lawson Health Research Institute (Canada), and Univ. of Western Ontario (Canada); B. Kaminska, Simon Fraser Univ. (Canada); J. J. L. Carson, Lawson Health Research Institute (Canada) and Univ. of Western Ontario (Canada) 
8234 IP SPR prism sensor using laser line generator [8234-59]

B. L. Chan, S. Jutamulia, Univ. of Northern California (United States)

8234 IR Three-dimensional gold nanorods-doped multicolor microstructures [8234-62]

C.-H. Lien, K.-C. Cho, W.-S. Kuo, C.-Y. Lin, C.-L. Chui, S.-J. Chen, National Cheng Kung Univ. (Taiwan)

Author Index 
Downloaded From: https://www.spiedigitallibrary.org/conference-proceedings-of-spie on 26 Apr 2023

Terms of Use: https://www.spiedigitallibrary.org/terms-of-use 


\title{
Conference Committee
}

\author{
Symposium Chairs
}

James G. Fujimoto, Massachusetts Institute of Technology (United States)

R. Rox Anderson, Wellman Center for Photomedicine, Massachusetts General Hospital, Harvard School of Medicine (United States)

Program Track Chairs

Paras Prasad, SUNY/Buffalo (United States)

Dan V. Nicolau, The University of Liverpool (United Kingdom)

Conference Chairs

Tuan Vo-Dinh, Duke University (United States)

Joseph R. Lakowicz, University of Maryland School of Medicine (United States)

Program Committee

A. Claude Boccara, Ecole Supérieure de Physique et de Chimie Industrielles (France)

Michael T. Canva, Laboratoire Charles Fabry (France)

Volker Deckert, Institut für Photonische Technologien e.V. (Germany)

Bruce S. Dunn, University of California, Los Angeles (United States)

Christopher D. Geddes, University of Maryland, Baltimore (United States)

Zygmunt Karol Gryczynski, University of North Texas Health Science Center at Fort Worth (United States)

Naomi J. Halas, Rice University (United States)

Jiri Homola, Institute of Photonics and Electronics of the ASCR, v.v.i. (Czech Republic)

Aaron Ho-Pui, The Chinese University of Hong Kong (Hong Kong, China) Laura Maria Lechuga, Centre d'Investigacions en Nanociència i Nanotecnologia (Spain)

Boris Mizaikoff, Universität Ulm (Germany)

Shuming Nie, Emory University (United States)

Weihong Tan, University of Florida (United States)

Andrew Taton, University of Minnesota, Twin Cities (United States)

Richard P. Van Duyne, Northwestern University (United States)

Jeffrey I. Zink, University of California, Los Angeles (United States) 
Session Chairs

1 Plasmonics and SERS I

Tuan Vo-Dinh, Duke University (United States)

2 Plasmonics and SERS II

Tuan Vo-Dinh, Duke University (United States)

3 Plasmonics Detection and Imaging

Michael T. Canva, Laboratoire Charles Fabry (France)

Brian C. Wilson, Princess Margaret Hospital (Canada)

Jean-François Masson, Université de Montréal (Canada)

$4 \quad$ Plasmonic Biosensing

Mustafa Culha, Yeditepe University (Turkey)

$5 \quad$ Plasmonic Nanostructures

Boris Mizaikoff, Universität Ulm (Germany)

6 Plasmonics and Fluorescence I

Joseph R. Lakowicz, University of Maryland School of Medicine (United States)

7 Plasmonics and Fluorescence II

Joseph R. Lakowicz, University of Maryland School of Medicine (United States)

8 Plasmonic Applications I

Joseph R. Lakowicz, University of Maryland School of Medicine (United States)

9 Plasmonic Applications II

Ho-Pui A. Ho, The Chinese University of Hong Kong (Hong Kong, China) 